\title{
Asylsøkere bør ha helsekort
}

Hvis asylsøkere har et helsekort som tas med til alle helserelaterte undersøkelser, kan det hindre dobbeltarbeid og unødvendig e tester.

\section{Forfattere}

\section{Olivia B. Obtinario}

Enhetsleder

Sauda legesenter, fysioterapitjeneste og helsestasjon

\section{Nøkkelord}

Asylsøker Helse Kvalitet

Sykepleien 2017 105(4)(48-51)

DOI: https://doi.org/10.4220/Sykepleiens.2017.61298

\section{HOVEDBUDSKAP}

Per i dag finnes det ingen verktøy eller prosedyrer for å kvalitetssikre det kliniske forløpet i helseundersøkelser av asylsøkere. Vi har derfor utarbeidet et helsekort som skal gjøre dette. Dermed blir helseundersøkelsene mer effektive og sikrer at asylsøkerne får helsetjenester i henhold til anbefalinger fra Helsedirektoratet. 
Norsk Sykepleierforbund har i samarbeid med International Council of Nurses startet et lederutviklingsprogram, Leadership for Change. Målet med programmet er å utvikle og styrke sykepleieres lederskap gjennom blant annet politiske utfordringer og god planlegging av helse- og omsorgstjenesten. Jeg deltok i dette programmet, som startet i januar 2016 og ble avsluttet i januar 2017. I løpet av programmet skulle hver deltaker jobbe med et prosjekt som hadde relevans i sykepleieryrket.

\section{Prosjektets hensikt}

Prosjektet mitt hadde følgende problemstilling: «Hvordan kan sykepleiere gjennomføre en effektiv og kvalitetssikret helseundersøkelse av asylsøkere som kommer til kommunene?» Vi ønsket et standard klinisk forløp og prosedyrer som skal brukes rutinemessig i helseundersøkelse av asylsøkere.

Hensikten med prosjektet var å bidra til at nyankomne asylsøkere får den somatiske og psykiske helseundersøkelsen som Helsedirektoratet beskriver i veileder IS-1022. Jeg ønsket å utarbeide et helsekort som kan effektivisere og kvalitetssikre det kliniske forløpet i helseundersøkelser av asylsøkere.

Videre ville jeg gjennomføre en tidsbegrenset prøveordning der asylsøkere blir utstyrt med et slikt helsekort. I ettertid skulle prøveordningen evalueres.

Vi ville bedre kvaliteten på helseundersøkelser av asylsøkere og ønsket en strukturert og kvalitetssikret flyt i helseundersøkelser av asylsøkere. Vi ville også forhindre dobbeltarbeid og fremme effektiv bruk av ressurser.

\section{Problemområder}

Veilederen for helsetjenestetilbudet til asylsøkere, flyktninger og familiegjenforente, IS-1022, ble justert og revidert for å imøtekomme den store tilstrømmingen av asylsøkere, som startet høsten 2015. 


\section{«Helseundersøkelse av asylsøkere er en stor utfordring for helsepersonell.»}

Jeg har utført en kartlegging som viser at helseundersøkelse av asylsøkere er en stor utfordring for helsepersonell. Det er tre problemområder som går ut over effektiviteten i den praktiske gjennomføringen av helseundersøkelse. Disse problemområdene henger sammen og påvirker hverandre:

- Asylsøkere flytter mye, ofte fordi mottak nedlegges og opprettes. En del asylsøkere søker selv om flytting til annet mottak. Det kan også være at den lokale helsetjenesten ikke blir informert om når og hvor asyls $\varnothing$ kere flyttes.

- Det er kommunikasjonsproblemer helsetjenester imellom. Helsetjenesten i ulike kommuner eller på ulike steder har forskjellige journalsystemer som ikke kommuniserer med hverandre. Det blir vanskelig for den lokale helsetjenesten å vite hvilke helsetjenester som er gjennomført i tidligere mottak (ankomstsenter, transitt, midlertidig mottak, ordinært mottak). Helsepersonell mangler ofte opplysninger om hvor asylsøkeren har oppholdt seg i Norge tidligere, og asylsøkeren selv har ofte problemer med å gjøre rede for det.

- Flyttemønster og kommunikasjonsproblemer øker risikoen for dobbeltarbeid for helsepersonell, noe som betyr en belastning for asylsøkeren og en dårlig utnyttelse av helsetjenestens ressurser og tidsbruk.

\section{Kartlegging}

Per i dag finnes det ingen verktøy eller prosedyrer for å kvalitetssikre det kliniske forløpet i helseundersøkelser av asylsøkere. På bakgrunn av dette valgte jeg et tema om migrasjon, nærmere bestemt helsearbeid for asylsøkere. Helsekortprosjektet var i samarbeid med Nasjonalt kompetansesenter for migrasjons- og minoritetshelse (NAKMI). Dette samarbeidet kvalitetssikret en faglig gjennomføring av prosjektet. 
Sammen med NAKMIs representanter, leder

Bernadette Kumar, konsulent Ragnhild Magelssen og seniorrådgiver Harald Siem, var jeg på studietur på Ankomstsenter Østfold i Råde. Målet var å se ankomstforløpet til asylsøkere. Vi fikk omvisning av Sarah Frandsen Gran, leder for ankomstsenteret.

For å få rede på hvilke utfordringer som opptar kommunene, sendte jeg ut 140 spørreskjemaer med sju spørsmål til helsestasjoner i 132 kommuner. Noen kommuner har flere helsestasjoner. Jeg hentet asylmottakslisten fra UDIs liste i januar 2016 (1).

Jeg fikk 84 svar med mange utfyllende kommentarer. De tre første spørsmålene forteller litt om hvilken type asylmottak den enkelte kommunen har (se faktaboks under[[nid:61352 | Ulike typer mottak | Faktaboks]]):

\begin{tabular}{|l|l|}
\hline Transitt & 7 \\
\hline Akutt & 12 \\
\hline Ordinær & 77 \\
\hline Totalt & 96 \\
\hline
\end{tabular}

\section{ULIKE TYPER MOTTAK}

Transittmottak er mottakssentraler opprettet som første oppholdssted for nyankomne som ønsker asyl. På slike mottak er de mens søknadene blir vurdert. Fra transittmottak går veien enten ut igjen av landet, til asylmottak eller til privat boforhold.

Akuttmottak (midlertidige mottak) er plasser som ble etablert for å sikre alle asylsøkere et tilbud når det ikke er plass i ordinære mottak. Asylsøkerne mottar ikke lommepenger verken i transitt eller i de midlertidige mottakene. Derfor er helsetjenestene og medisinene legen forskriver der, gratis. 
Asyls $\emptyset$ kere flyttes til ordinære mottak etter asylintervju hos Utlendingsdirektoratet (UDI). Her bor asyls $\varnothing$ kere mens søknaden deres blir behandlet. De bor gratis, men må betale kosten selv. De får lommepenger som skal dekke mat, klær, helsetjenester og nødvendige medisiner, med noen unntak eller med mulighet for ekstra støtte.

Summen er høyere enn antall svar fordi noen kommuner har flere typer mottak:

\begin{tabular}{|l|l|}
\hline Transitt og akutt & 1 \\
\hline Transitt og ordinær & 2 \\
\hline Ordinær og akutt & 8 \\
\hline Ordinær, transitt og akutt & 1 \\
\hline Totalt & 12 \\
\hline
\end{tabular}

Jeg stilte også spørsmål om hvor mange asylsøkere kommunen kan ta imot:

\begin{tabular}{|l|l|}
\hline Under 100 & 4 \\
\hline $100-150$ & 10 \\
\hline $151-200$ & 16 \\
\hline $201-300$ & 31 \\
\hline Over 300 & 12 \\
\hline
\end{tabular}

Elleve kommuner svarte ikke på spørsmålet.

Kommuner som sendte tilbakemelding, er jevnt fordelt geografisk:

\begin{tabular}{|l|l|}
\hline Nord-Norge & 20 \\
\hline & \\
\hline
\end{tabular}




\begin{tabular}{|l|l|} 
Sør-Norge & 18 \\
\hline$\varnothing$ st-Norge & 21 \\
\hline Vest-Norge & 21 \\
\hline Midt-Norge & 2 \\
\hline
\end{tabular}

To kommuner svarte ikke på spørsmålet.

Veilederen fra Helsedirektoratet anbefaler å

gjennomføre tuberkuloseundersøkelse innen to dager,

og senest innen 14 dager etter ankomst.

På spørsmål om kommunen utfører eller initierer tuberkulosekontroll, er svarene som følger:

\begin{tabular}{|l|l|}
\hline Ja & 52 \\
\hline Nei & 6 \\
\hline Av og til & 24 \\
\hline Ikke svart & 2 \\
\hline Totalt & 84 \\
\hline
\end{tabular}

Kartleggingen viser at over halvparten av helsestasjonene gjennomfører tuberkulosekontroll fordi de ikke får nødvendig helseinformasjon i tide fra tidligere vertskommune. Tilbakemeldinger bekrefter at tuberkulosekontroll initieres som et forebyggende tiltak. Gjentatte helseundersøkelser gir asylsøkerne en unødvendig påkjenning fordi de må ta flere blodprøver. I tillegg fordobles kostnaden og tiden som brukes til helseundersøkelsen.

På spørsmål om kommunen klarer å gjennomføre helseundersøkelse innen angitt tid, viser kartleggingen følgende: 


\begin{tabular}{|l|l|l|l|l|}
\hline & Ja & Nei & Vet ikke & Av og til \\
\hline Helsesøster & 58 & 17 & & 4 \\
\hline Lege & 40 & 26 & & 2 \\
\hline Jordmor & 49 & 11 & 1 & \\
\hline Undervisning & 13 & 41 & 1 & 1 \\
\hline
\end{tabular}

Med undervisning menes helserelatert undervisning, for eksempel kost/ernæring, hygiene, seksualundervisning med mer.

Kommunene utfører tjenestene forskjellig. De fleste kommuner gjennomfører helsesøstersamtale. I noen kommuner gjennomføres helsesøstersamtale og legeundersøkelser kun etter indikasjon eller henvendelse fra mottak. Noen helsestasjoner gjennomfører helsesøstersamtaler kun etter at journalene er på plass. Asylsøkere får tilbud om legeundersøkelse eller frivillig tjeneste bare ved behov.

Legeundersøkelse er en betalingstjeneste. Noen kommuner venter til asylsøkerne har fått D-nummer før de gjennomfører legeundersøkelse (se faktaboks lenger ned). Da har asylsøkeren fått fastlege som tar ansvar for legeundersøkelsen. Noen kommuner gjennomfører legeundersøkelse kun når helsejournalen foreligger. Jordmortjenesten fungerer bra i de fleste kommunene.

Noen kommuner gir nødvendig helseundervisning under helsesamtalen. Ellers er det asylmottak som organiserer undervisning med hjelp fra de forskjellige fagområdene.

Tid og ressurser er de største utfordringene de fleste kommuner har, ifølge kartleggingen: 


\begin{tabular}{|l|l|}
\hline Ressurser & 57 \\
\hline Verktøy & 17 \\
\hline Ikke svart & 3 \\
\hline
\end{tabular}

\section{Mye tar tid}

I kommentarene kommer det frem at mye tid går med til å spore opp blodprøver og journaler. Det er også tidkrevende å hente inn informasjon om hva som er gjort og hva som gjenstår.

\section{三 «Mye tid går med til å spore opp blodprøver og journaler.»}

Bruk av tolk er en stor utfordring. Erfaringer viser at noen tolketjenester ikke holder mål. Ofte er det dårlig eller feil oversetting og mye feiltolkning. Tolketjenesten går på anbud, slik at det billigste firmaet får oppdraget på grunn av kommunens dårlige økonomi. Dette påvirker resultatet av helseundersøkelsen. Det er også tidkrevende å bruke tolk, men absolutt nødvendig. Det er mangel på brosjyrer og informasjonshefter om blant annet vaksiner og psykisk helse oversatt til rett språk.

Det er utfordrende å organisere og gjennomføre helseundervisning fordi asylsøkerne snakker flere språk. Flere gruppeundervisninger vil kreve flere undervisningstimer for helsepersonellet.

Det er få kvalifiserte ansatte som jobber med asylarbeid og gjennomgående få årsverk. Helsesøster må gjøre veldig mye merkantilarbeid, som å bestille legetime og hente inn blodprøvesvar.

Legeundersøkelse blir fordelt på fastleger på legekontor. Det er få eller ingen psykologer eller psykiatere i kommunene. Dette gir utfordringer ved henvisning til og oppfølging av psykolog eller psykiater. 


\section{Mangler ressurser}

Det er til tider stort press på grunn av stor tilstrømning av asylsøkere. En del av de obligatoriske oppgavene på helsestasjonen, slik som skolehelsetjeneste, blir utsatt for å gi tid til asylsøkerarbeid. Den tidvis store utskiftingen av asylsøkere fører til at ikke alle kommer gjennom helseundersøkelse før de reiser til neste sted. Vaksinasjon prioriteres.

\section{三 «Asylmottak og helsestasjon mangler verktøy, kommunikasjon og samarbeid.»}

Asylmottak og helsestasjon mangler verktøy, kommunikasjon og samarbeid. Journalene blir ikke sendt videre til neste sted. Journalen er veldig viktig for å vurdere og behandle ved sykdom. Mens noen venter på journaler, blir en del journaler liggende igjen en annen plass fordi de ikke vet hvor asylsøkeren ble flyttet. Noen helsesøstre har ikke tilgang til kontor for helseundersøkelse.

Asylsøkernes holdning påvirker gjennomføringen av helseundersøkelse. De kommer ofte sent, og dermed forsinker de resten av dagens oppgaver. Ganske ofte møter ikke asylsøkeren opp til legetimen.

\section{Forslag om helsekort}

Et tiltak som jeg foreslo i undersøkelsen, er å bruke helsekort. Helsekort er tenkt som et kort eller hefte som asylsøkere får ved første møte med helsetjenesten i Norge. Asylsøkeren skal ha helsekortet med seg til alle helserelaterte undersøkelser. Det skal loggføres hvor asylsøkeren har vært og skal, hvilken helsetjeneste vedkommende har mottatt samt hvor og når denne tjenesten ble mottatt. Helsekortet blir et veiledende verktøy for helsepersonellet.

Kortet skal inneholde følgende:

- Identitet

- Etternavn 
- Fornavn

- Fødselsdato

- D-nummer (se faktaboks under)

- DUF-nummer (se faktaboks under)

- Land

- Språk

- Vaksinasjonsoversikt

- Reiseoversikt

- Oversikt over helseunders $\varnothing$ kelse

- Røntgen av thorax

- Tuberkulosetesten IGRA (Interferon-Gamma Release Assays), som er mer spesifikk en tuberkulintesten

- Anbefalte blodprøver

\section{D-NUMMER OG DUF-NUMMER}

$D$-nummer er et nummer som kan tildeles utenlandske personer som ikke har norsk fødselsnummer, men som trenger et D-nummer ved identifisering overfor norske myndigheter. Det kan for eksempel være for å betale skatt eller avgift eller motta trygd. Det er kun personer som skal oppholde seg i Norge mindre enn seks måneder som kan tildeles D-nummer.

Et DUF-nummer er et tolvsifret nummer som blir gitt til alle som søker om opphold i Norge. DUF-nummeret er søkerens registreringsnummer i UDIs datasystem.

Kilder: Altinn og UDI

Jeg stilte spørsmål om helsekort kan bidra til å effektivisere og kvalitetssikre helseundersøkelse av asylsøkere. Svarene er som følger:

\begin{tabular}{|l|l|}
\hline Ja & 66 \\
\hline Nei & 1 \\
\hline Mulig & 13 \\
\hline Ikke svart & 4
\end{tabular}




\section{Fordeler med helsekort}

Deltakerne kommenterte at det ofte tar lang tid før tuberkulosestatusen kommer til kommunene. Helsekort kan bidra til å unngå dobbeltarbeid. Helsekort vil også forenkle oversikten over hva som er gjort og hva som skal gjøres. Helsekortet vil dessuten være til stor hjelp for å sikre god flyt av helseinformasjon. Det var gjennomgående enighet om at helsekortet vil bidra til en mye bedre kvalitetssikring av tjenesten.

Det er flere forutsetninger for at helsekort kan bli et bra verktøy. Asylsøkere må forstå hva helsekortet er og hvor viktig det er å ta kortet med til hver helseundersøkelse, både til lege, jordmor og helsesøster. Alle instanser og stoppesteder må fylle ut helsekortet. Det må gis god informasjon om bruk av helsekort.

I tillegg må informasjonsutvekslingen mellom asylmottak og helsestasjon eller helsesøster bedres. Det er essensielt at kortet inneholder viktige opplysninger, inkludert D-nummer og DUF-nummer. Opplysninger må gis i samråd med Helsedirektoratets veileder IS-1022. Det er også viktig at helsekort lages av materiell av god kvalitet fordi det skal tas med til og bli brukt under alle helserelaterte undersøkelser. Kortet skal ikke erstatte journalen.

Det er allerede utviklet et helsekort i EU. Det har kommet tilbakemeldinger om at EUs helsekort er svært omfattende, og derfor har det ikke vært så mye brukt.

Hensikten med helsekortet vi har utarbeidet, er å kvalitetssikre det kliniske forløpet. Dermed blir helseundersøkelsene mer effektive og sikrer at asylsøkerne får helsetjenester i henhold til anbefalinger fra Helsedirektoratet.

\section{Status på prosjektet}


Vi hadde planlagt å kjøre et pilotprosjekt med helsekortet. Som en prøveordning ønsket vi å dele ut 50 helsekort, fortrinnsvis på ankomstsenter eller transittmottak for enslige mindreårige asylsøkere mellom 15 og 18 år. Prosjektet ville ha gitt oss verdifull informasjon om det kliniske forløpet og om helseundersøkelsene som ble gjennomført.

Imidlertid bestemte Helsedirektoratet i 2016 at manuelle helsekort ikke skulle brukes (2). Dermed ble det vanskelig å motivere deltakerne, og vi bestemte oss for ikke å gjennomføre pilotprosjektet.

Vi skal ha en posterpresentasjon av prosjektet på International Council of Nurses Congress i Barcelona i mai 2017. Da håper vi noen andre land interesserer seg for helsekortet.

\section{Referanser}

1. UDI. Asylmottak. Adresser til asylmottakene.

Tilgjengelig fra:

https://www.udi.no/asylmottak/adresser-tilasylmottakene/. (Nedlastet 10.01.2016).

2. Moe B. - Manuelt helsekort for asylsøkere er uegnet. Tilgjengelig fra:

(https://sykepleien.no/meninger/innspill/2016/10/manuelthelsekort-asylso...). (Nedlastet 17.03.2017). 